\title{
Effects of Plant Growth Regulators on the In Vitro Cultures of Vitis vinifera $\mathbf{L}$.
}

\author{
Ersen Cakal \\ Canakkale Onsekiz Mart University, School of Graduate Studies, \\ Subdivision of Biology, 17020, Canakkale, Turkey \\ E-mail: ersencakal@gmail.com \\ Cuneyt Aki \\ Canakkale Onsekiz Mart University, Faculty of Science and Arts, \\ Department of Biology, Subdivision of Molecular Biology, 17020, Canakkale, Turkey \\ E-mail: cuneytaki@comu.edu.tr
}

\begin{abstract}
Vitis vinifera L. (grape) is a plant that is cultivated extensively in the world and in our country because of it's economic importance. Grape fruit can be use as juice, molasses, wine and medicinal industry. Although there are many types of genetically potent grape varieties, today there is a growing demand for varieties with high yield and quality, especially resistant to stress factors. The aim of our research were comparison of MS and Gamborg nutrient mediums on in vitro grape callogenesis levels. In this research, petiole and shoot tip explants which taken from two years old $V$. vinifera Bozcaada Cavus Grape cv. seedlings were cultured on MS0 and Gamborg mediums for callogenesis. After healthy callus biomass have been obtained from different explant types of the grape on MS0, this callus cultures have been transferred to the MS mediums which supplemented with $1: 1 \mathrm{mg} / \mathrm{mL}$ BAP:2,4-D together. Gamborg medium has been eliminated because of no callogenesis. The effects of combinations of plant growth regulators on the callus have been determined by the means of biomass levels. Subculture series was observed across four subcultures. As a result, MS medium which supplemented with BAP and 2,4-D together choosed for the callogenesis experiments and callogenesis induction has been increased \%80 when we compare with MS0 medium. There are no research have been found on petiole and shoot tip explants of this cultivar which cultured on MS and Gamborg mediums for callogenesis. In our research, it has been demonstrated that different nutrient medium types and plant growth regulators have been efffective on callogenesis in different levels.
\end{abstract}

Keywords: Vitis vinifera, in vitro culture, BAP (benzylaminopurine), 2,4-D (2,4-Dichloropheno xyacetic acid)

DOI: $10.7176 /$ JSTR/7-04-05

\section{Introduction}

Grape vine is a plant that is cultivated extensively in the world and in our country and has high economic importance. Researchers have been using in vitro culture techniques for develop new quality substances from grape. The history of the grape vine plant goes back thousands of years. It is the region that includes the Caucasus, which is called Asia Minor, which includes its homeland Anatolia. Compared to other fruits, it is one of the types with the most variety. It is estimated that there are over 10,000 grape varieties. The varieties that are native to Anatolia are over 1200. About 50-60 of them are economically produced. (https:/www.turkcebilgi.com/üzüm). Grape vine is a plant that is widely cultivated in the world and in our country and is of high economic importance. Grape fruit pulp, molasses, grape juice, wine and so on. It is presented to consumption in different ways.

In the world, viniculture is carried out on an area of 7.155.187 hectares and approximately 77.000.000 tons of grapes are produced. Turkey 468.792 hectares of land in the world with 4.011.409 tons of grape production meets the $5.20 \%$. Our country contains many medicinal and aromatic plants with its rich flora. The use of herbs in treatment started with the history of humanity. Thousands of years ago,

39 | P a g e

www.iiste.org 
people recognized the therapeutic power of herbs and took advantage of them to live healthy. Folk remedies in Anatolia, where folk medicine practices are common, are practices that have survived to the present day after long experiences. Many drugs used in modern medicine are also obtained from plants. Vegetable wealth in our country; The fact that it is located at the intersection of three phytogeographical regions, that it is a bridge between Southern Europe and Southwest Asia, is the origin and differentiation center of many genera and sections. Despite this, this plant richness cannot be utilized sufficiently. Microorganisms of plants have been investigated in laboratories since 1926, with their lethal and important properties for human health. According to World Health Organization (WHO) research, the number of medicinal plants used for treatment is around 20.000. As in all over the world, in our country, the natural flora of Turkey is for therapeutic purposes, food, tea, spices, dyes, insecticides, treatment of animal diseases, resin, gum, essential oils, and the use of our traditional cultural wealth in the beverage and cosmetics industry for many years has been a part of it (Faydaoğlu, 2011)

Belonging to the Vitaceae (grape vine) family, $V$. vinifera L. cv. Sultani (seedless Sultani grape) is one of our important export products, especially grown in Western Anatolia. From past centuries to the present, many varieties belonging to some species of the Vitis genus have been commercially produced. However, studies are needed to obtain varieties with high yield and quality, resistant to various stress factors or tolerant to changing market demands. However, the long generation period of the vine and its high heterozygous nature limit the obtaining of suitable varieties with traditional breeding studies. For this reason, the development of biotechnological methods in plants and their use for breeding is of great importance to eliminate the difficulties encountered in traditional breeding studies (Altun, 2010).

In another research, in vitro regeneration of grape vine with somatic embryogenesis and organogenesis was performed from different explants sources in different grape species and varieties. (Gray, 1992).

In the regeneration of grape vine through organogenesis and somatic embryogenesis, shoots were obtained from leaves, petioles, roots and internodes formed from leaves were transferred to MS and Nitsch and Nitsch (NN) semi-solid culture media in which supported with BAP, IBA and IAA, 2,4-D, NAA (Özden, 2008).

Researchers have been determined the organogenic potential of leaf explants taken from in vitro shoots of 18 grape vine genotypes. Leaf explants were cultured on MS medium containing $2 \mathrm{mg} / \mathrm{L}$ BA and $0.03 \mathrm{mg} / \mathrm{L}$ NAA. In this regeneration system, a high rate of shoot formation was achieved from leaf explants of Sultana moscato, Riesling, Chardonnay, Cabernet franc genotypes (Martinelli, 1996).

In another research, five grape varieties (Atasarıs1, Sergeant, Kalecik black, Sultan seedless and Yapıncak) and two grape rootstocks (Kober 5BB and 41B MG), adventitious leaf and petiole explants obtained from the in vitro shoots of varieties and rootstocks. The effects of genotype, explant source and nutrient media on shoot formation were investigated. At the end of the study, the highest values with adventitious shoot development were obtained from MS which supplemented with $2 \mathrm{mg} / \mathrm{L} \mathrm{BA}$ and NN nutrient media where leaf stalk explants were taken into culture (Baydar, 1998a).

The effect of two nutrient mediums (MS, B5) and different explant types (internodal parts, petiole) on obtaining appropriate callus for four different grape varieties (Kalecik black, Öküzgözü, Erciş, Cabernet Sauvignon) have been reported (Keskin, 2010).

In one of the research, researchers used plant cell cultures obtained from petioles of Gamay (GT) and Cabernet Sauvignon races (CS4 and CS6) and used media containing macro elements, microelements and vitamins as well as $58 \mathrm{mM}$ sucrose and $250 \mathrm{mg} / \mathrm{L}$ casein hydrolyzate as nutrients. However, they also used methyl jasmonate and phenyl alanine together with some growth regulators. $0.5 \mu \mathrm{M}$ NAA and $1.0 \mu \mathrm{M}$ kinetin for the Gamay variety as growth regulators; They used $2.5 \mu \mathrm{M}$ NAA and $0.5 \mu \mathrm{M}$ benzyl amino purine (BAP) for the Cabernet Sauvignon variety. The researchers, culturing the cultures they obtained in this way under 5000 lux light and at $25^{\circ} \mathrm{C}$, subcultured the 7 days cultures in a medium containing $2.0 \mathrm{mM}$ (NH4) 2SO4, $2.2 \mathrm{mM} \mathrm{NaH} 2 \mathrm{PO} 4,2.0 \mathrm{mM} \mathrm{MgSO} 4$ and $175 \mathrm{mM}$ sucrose (Krisa, 1999).

As a result of the literature review, there are no research have been found on petiole and shoot tip explants of $V$. vinifera Bozcaada Çavuş Grape cultivar seedlings which cultured on MS and Gamborg mediums for callogenesis. This cultivar which used as a plant material in our research grows in Marmara Region especially Bozcaada-Çanakkale and Central Anatolia Region. In our research, it has been demonstrated that different nutrient medium types have been efffective on callogenesis in different levels. 


\section{Material and Methods}

\subsection{Plant Material}

Vitis vinifera L. Bozcaada Çavuş Grape cultivar used as plant material has been obtained from Gülsa Floristry Ltd., Çanakkale.

\subsection{Surface Sterilization and Explant Transfer}

$V$. vinifera L. petiole and shoot tips were immersed in $70 \% \mathrm{EtOH}$ for two minutes, then immerse to different concentrations and exposure times of sodium hypochlorite $(\mathrm{NaOCl})$ solutions at the and of surface sterilization process all of the explants types rinsed with distilled water three times (Table 1).

Table 1. Surface sterilization of $V$. vinifera petiole and shoot tips explants.

\begin{tabular}{|c|c|c|}
\hline Sterilization Number & Ethanol (\%70) & NaClO \\
\hline 1 & 2 min. & 10 min. $\% 10$ \\
\hline 2 & 2 min. & 15 min. $\% 10$ \\
\hline 3 & 2 min. & 20 min. $\% 10$ \\
\hline 4 & 2 min. & 10 min. $\% 15$ \\
\hline 5 & 2 min. & 15 min. $\% 15$ \\
\hline 6 & 2 min. & 20 min. $\% 15$ \\
\hline 7 & 2 min. & 10 min. $\% 20$ \\
\hline 9 & 2 min. & 15 min. $\% 20$ \\
\hline
\end{tabular}

\subsection{Nutrient Medium Preparation}

MS (Murashige and Skoog) and Gamborg B5 medium were prepared for $V$. vinifera petiole and axillary shoot tips explant transfer. For the MS medium preperation; 4,4 grams of medium, 30 grams of sucrose, 8 grams of agar added per liter to the medium, $\mathrm{pH}$ was adjusted to 5.7 and sterilized in autoclave. For Gamborg B5 medium preperation; 3,2 grams of medium, 20 grams of sucrose, 8 grams of agar were added per liter, $\mathrm{pH}$ was adjusted to 5.7 and then sterilized in autoclave.

\subsection{Transfer of Explants}

MSO and Gamborg B5 medium sterilized in autoclave were poured into petri dishes of $25 \mathrm{ml}$ and 40 of them. After the preparation of petri dishes, explants transferred to the each petri dishes approximately 1 $\mathrm{cm}$ diameter in size with four explants in each petri dish and kept in the controlled plant growth room under optimum conditions for callus formation. Explants in MS0 and Gamborg B5 medium were subcultured once a month for three times.

Explants which showing callus growth were transferred to the petri dishes with MS medium with the addition of plant growth regulators. After this transfer in the laminar flow, all petri dishes were placed in the plant growing room under optimum conditions. 21 days after explant transfer, explants were transferred to MS medium containing concentrations of $1 \mathrm{mg} / \mathrm{mL} 2,4-\mathrm{D}$ and $1 \mathrm{mg} / \mathrm{mL}$ BAP. The explants were observed by taking three more subcultures in plant growth regulators.

\section{Results and Discussion}

\subsection{Surface Sterilization and Callus Formation Results of Vitis vinifera L. Explants}

Depending on the ethanol and $\mathrm{NaOCl}$ concentration used for surface sterilization, changes in the percentages of browning and contamination were observed. The best sterilization results obtained in $V$.

41 | P a g e 
vinifera variety were obtained by keeping it in $\mathrm{NaOCl}$ prepared at $20 \%$ concentration for 15 minutes. The browning and contamination results obtained among these groups are given in Table 2.

Table 2. Surface sterilization results.

\begin{tabular}{|c|c|c|}
\hline Sterilization Number & Contamination (\%) & Callus Browning (\%) \\
\hline 1 & $86,60 \pm 5,63$ & - \\
\hline 2 & $73,33 \pm 5,48$ & - \\
\hline 3 & $63,38 \pm 5,26$ & - \\
\hline 4 & $73,33 \pm 5,19$ & $6,72 \pm 5,57$ \\
\hline 5 & $66,65 \pm 4,85$ & $16,67 \pm 5,13$ \\
\hline 6 & $56,68 \pm 4,38$ & $6,63 \pm 4,78$ \\
\hline 7 & $50,58 \pm 4,23$ & $13,38 \pm 3,16$ \\
\hline 8 & $10,75 \pm 3,25$ & $33,34 \pm 3,43$ \\
\hline 9 & $10,45 \pm 3,25$ & - \\
\hline
\end{tabular}

\subsection{Callus Growth Results}

After the $V$. vinifera explants transferring to the Gamborg B5 and MS0 medium, callus induction have been observed during three subcultures series for three months. As a result of the observations made, it was seen that $V$. vinifera explants had more appropriate to the MS medium in terms of callus development (Figure 1).

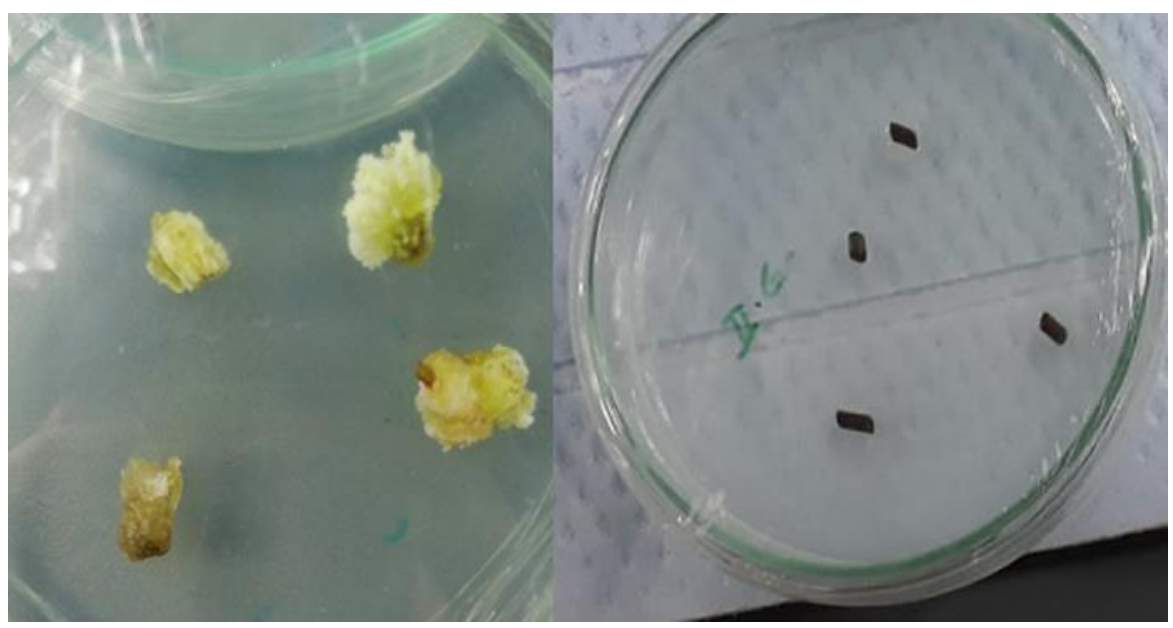

(A)

(B)

Figure 1. Callus development after three weeks in a) MS0 and b) Gamborg B5 
Table 3. Callus growth percentages in MS and Gamborg B5.

\begin{tabular}{|c|c|c|}
\hline \multirow{2}{*}{ Number of Subcultures } & \multicolumn{2}{|c|}{ Callus Growth (\%) } \\
\cline { 2 - 3 } & MS0 & Gamborg \\
\hline 1 & $72,45 \pm 5,52$ & $21,33 \pm 4,21$ \\
\hline 2 & $85,36 \pm 3,28$ & $19,45 \pm 3,85$ \\
\hline 3 & $84,42 \pm 4,41$ & $12,45 \pm 2,85$ \\
\hline
\end{tabular}

As a result of our research, it was determined that callus development is less in subcultures in the B5 medium and this decreases gradually from the first subculture to the third subculture. On the other hand, it was observed that the subcultures prepared in MS0 had higher callus growth compared to B5 medium. A comparison of growth percentages in Gamborg B5 and MS medium is shown in Table 3.

When compared to MSO, callus growth potential of $V$. vinifera was found higher than MSO in plant growth regulator supplemented medium. As can be seen in Figure 2, it is observed that plant growth regulators increase callus development.

The first group (a) with callus development was divided into two parts and taken into the second (b) subculture, and it was found that the development increased by observing callus growth in a hormone environment. The highest amount of development was observed in the third (c) and last subculture. First (a), second (b) and third (c) subcultures of explants in medium supplemented with plant growth regulators (Figure 2).

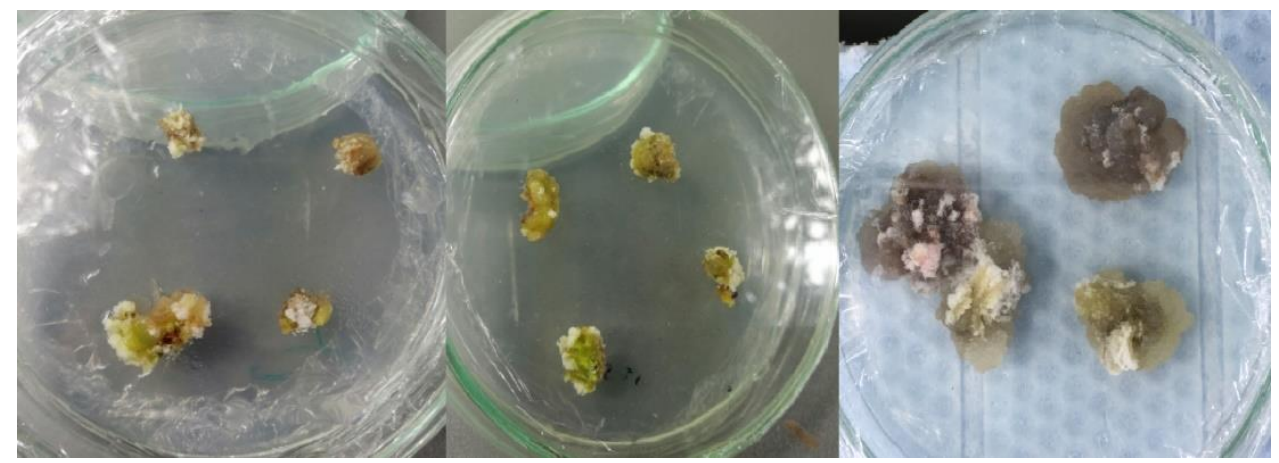

(A)

(B)

(C)

Figure 2. First (a), second (b) and third (c) subcultures of explants in MS medium supplemented with plant growth regulators.

\subsection{Discussion}

As a result of our research, the surface sterilization method of different explant types of Bozcada Çavuş Grapes at ideal concentrations was determined. It was determined that the explants transferred from the grape variety we used had a high percentage of callus growth.

Leaf stalks of the explant source for the most appropriate organogenesis in different rootstock varieties in a study; the most suitable nutrient medium for Kalecik Karası, Çavus, Sultani seedless and Kober 5BB with 2 mg / 1 BAP added MS (MS B); Will, Atasarıs1 and 41 B M.G. It has been determined that there is NN (NN B) medium with $2 \mathrm{mg} / 1$ BAP. In Kalecik Karas1 where leaf stalks were used as an explant source and cultured in MS B environment, the rate of explants forming adventitious shoots was $56.0 \%, 48.0 \%$ in Sultani seedless, $40.0 \%$ in Kober 5 BB, 34.7\% in Cavus; It was determined that leaf stems were used as the source of explants and it was 30.7\% in Atasarıs1, 34.7\% in Yapıncak and 16.0\% in 41 B M.G., grown in NN B environment (Baydar, 1998b).

According to a study, stem explants in grapevine plants gave the most efficient results in terms of direct

43 | P a g e

www.iiste.org 
and indirect adventitious shoot formation and callus growth in the environments is maximum $0.2 \mathrm{mg} / \mathrm{L}$ $\mathrm{BAP}+1 \mathrm{mg} / \mathrm{L} 2,4-\mathrm{D}+2.5 \mathrm{mg} / \mathrm{L}$ IBA containing MS and NN media containing only $2 \mathrm{mg} / \mathrm{L} 2,4-\mathrm{D}$, direct adventitious shoot growth and MS medium containing $2 \mathrm{mg} / \mathrm{L}$ zeatin and $\mathrm{NN}$ medium containing 2 $\mathrm{mg} / \mathrm{L} \mathrm{BAP}$, indirect adventitious shoot growth $0.2 \mathrm{mg} / \mathrm{L} \mathrm{BAP}+1 \mathrm{mg} / \mathrm{L} 2,4-\mathrm{D}+1 \mathrm{~g} / \mathrm{L}$ casein hydrolyzate added MS medium and $2 \mathrm{mg} / \mathrm{L}$ zeatin from $\mathrm{NN}$ medium were observed. While dark culture conditions have positive effects on callus formation; On the other hand, 16/8-hour illumination was determined to increase direct and indirect adventitious shoot development (Baydar, 2008).

According to our research results, $V$. vinifera callus induction was performed better in MS0 medium which supplemented with plant growth regulators than Gamborg B5 medium. Browning was observed in the esplants in the Gamborg B5 medium. In addition, callus growth remained in low amounts and healthy callus masses could not be obtained. In the MS medium, unlike Gamborg B5, callus growth was obtained in a healthier way and it was determined that their transfer to the subculture was successful.

\section{Conclusion}

As a result, the appropriate surface sterilization and plant growth regulators concentrations have been determined in the experiments on V. vinifera explants. According to our research results, the nutrient media and plant growth regulators that encourage the optimal growth and development of the vine explants callus induction in vitro conditions were determined.

\section{References}

Altun, O., Yürekli, A. K., 2000. Vitis vinifera L. CV. Sultani (Vitaceae)' de in vitro Kalsiyum değiş̧iminin kallogenez ve regenerasyon üzerine etkisi. BAÜ Fen Bilimleri Enstitüsü Dergisi. 2 (1).

Baydar, G., N., 1998. Asmada (Vitis spp.) Yapraklardan Adventif Sürgün Oluşumu Üzerine $\quad$ Bir Araştırma. Turk Journal Biol. 24, 645-656 TÜBITAK.

Baydar, G., N., 2008. ASMADA (Vitis vinifera L.) Gövde ve Yaprak Sap1 Eksplantlarından Adventif Sürgün Oluşumu Üzerine Bir Araştırma. Akdeniz Üniversitesi Ziraat Fakültesi Dergisi, 21(2), 231-240.

Faydaoğlu, E., Sürücüoğlu, M. S., 2011. Geçmisten Günümüze Tıbbi ve Aromatik Bitkilerin Kullanılması ve Ekonomik Önemi, Kastamonu Univ., Journal of Forestry Faculty, 11 (1): 52 67.

Gray, S. J., Meredith, C. P., 1992. Grape. Biotechnology of perennial fruit crops., 229-

Keskin, N., And Kunter, B., 2010. Asmada (Vitis Vinifera L.) in vitro I. Tip Kallus Eldesi Üzerine Çeşit, Besin Ortamı ve Eksplant Tipinin Etkisi. YYÜ TAR BİL DERG (YYU J AGR SCI), 2010, 20(2): 100-106.

Krisa, S., Larronde, F., Budzinski, H., Decendit, H., Deffieux, G., Me'Rillon, J. M., 1999. Stilbene Production by Vitis vinifera Cell Suspension Cultures: Methyl Jasmonate Induction and 13C Biolabeling. J. Nat. Prod. 1999, 62, 1688-1690.

Martinelli, L., Poletti, V., Bragagna, P., Poznanski, E., 1996. A study on organogenic potential in the Vitis genus. Laboratorio Biotecnologie, Istituto Agrario, San Michele all'Adige (TN), Italia. Vitis 35 (4), 159-161 (1996).

Özden, M., Demirel, U., Gürsöz, S., 2008. Öküzgözü ve Boğazkere (Vitis Vinifera L.) Üzüm Çeşitlerinin Yaprak Eksplantlarından Organogenesis Yoluyla Bitki Regerenasyonu. J.Agric.Fac.HR.U., 2008, 12(4):41-49. 